\title{
MENIMBANG WACANA FORMALISASI HUKUM PIDANA ISLAM DI INDONESIA
}

\author{
F a is a 1 \\ Fakultas Syariah IAIN Raden Intan Lampung \\ Jl. Letkol H. Endro Suratmin, Sukarame, Bandar Lampung \\ E-mail: hafaisal@yahoo.com
}

\begin{abstract}
The Possibility of an Islamic Criminal Law Formalization Discourse in Indonesia. In the discourse of law, criminal law is often viewed as a cruel and barbarian law. This view is based on an assumption that although the application of criminal law aims to restore social balance, it is undeniable that the application of the criminal contains elements of retaliation against the perpetrators of crime. This is reinforced by the severe punishment-oriented model of criminal deprivation of liberty in the form of imprisonment that dominates almost all penal systems of the nations of the world, including Indonesia. This paper proves that the Islamic criminal law legislation in the formalization of the State legislation has a positive contribution in a framework to enrich and bring together a form of awareness of the commitments of the nation and the state.
\end{abstract}

Keywords: law, crime, Islam, formalization, Indonesia

\begin{abstract}
Abstrak: Menimbang Wacana Formalisasi Hukum Pidana Islam di Indonesia. Dalam diskursus ilmu hukum, hukum pidana seringkali dipandang sebagai hukum barbarian yang kejam. Pandangan ini didasarkan pada sebuah asumsi bahwa meskipun penerapan pidana bertujuan untuk memulihkan keseimbangan sosial yang rusak, namun tidak dapat dimungkiri bahwa dalam penerapan pidananya terkandung unsur pembalasan terhadap pelaku kejahatan. $\mathrm{Hal}$ ini diperkuat dengan masih massifnya model pemidanaan yang berorientasi pada pidana perampasan kemerdekaan berupa penjara yang mendominasi hampir seluruh sistem pemidanaan negara-negara dunia, termasuk Indonesia. Tulisan ini membuktikan bahwa legislasi hukum pidana Islam ke dalam formalisasi perundang-undangan Negara memiliki kontribusi positif dalam rangka memperkaya sekaligus merekatkan kembali sebagai bentuk penyadaran terhadap komitmen dalam berbangsa dan bernegara.
\end{abstract}

Kata Kunci: hukum, pidana, Islam, formalisasi, Indonesia

\section{Pendahuluan}

Hukum pidana Islam atau Islamic criminal law menurut asas legalitasnya dikategorikan sebagai hukum yang tidak tertulis. Namun demikian, sebenarnya hukum pidana Islam dapat diakui secara konstitusional sebagai hukum yang terus berlaku. Hukum Islam masih sering dipersepsikan kurang baik di kalangan ahli hukum, birokrat, dan elit politik, sehingga berpengaruh besar terhadap persepsi masyarakat. Dalam literatur fikih, hukum pidana lebih dikenal dengan sebutan al-ạkkâm al-jinâiyyah, yaitu hukum-hukum yang mengatur ucapan, sikap, atau perbuatan orang-orang mukallaf yang berkenaan dengan pelbagai tindak pelanggaran atau kejahatan (jarimah/jinâyah) berikut jenis-jenis ancaman hukuman yang patut diberikan. ${ }^{1}$

${ }^{1}$ Wahbah al-Zuhaylî, al-Figh al-Islâmî wa' Adillatuh, (Damsyik: Dâr al-Fikr, 1989), h. 20; lihat pula, 'Abd al-Wahhâb Khalâf, Ilm Ushôl al-Fiqh, (Kairo: Dâr al-Kuwaitiyyah, 19680) h. 33.
Dalam pandangan al-Syâthibî, hukum Islam, termasuk juga hukum pidananya, ditempatkan untuk melindungi lima hak dasar/asasi manusia (aldharûriyyat al-khams), yang meliputi perlindungan terhadap jiwa ( $\underline{\text { hifzh }}$ al-nafs), perlindungan terhadap akal ( $\underline{\text { hifzh }}$ al-'aql), perlindungan terhadap agama ( $\underline{\text { iffzh }}$ al-dîn), perlindungan terhadap harta (

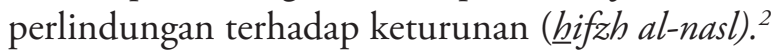

Tidak dapat dimungkiri bahwa umat Islam di Indonesia adalah unsur mayoritas. Dalam tataran dunia Islam internasional, umat Islam Indonesia bahkan dapat disebut sebagai komunitas Muslim paling besar yang berkumpul dalam satu batas teritorial kenegaraan. Dalam perspektif sosial budaya, membandingkan hukum pidana nasional dengan hukum pidana Islam

\footnotetext{
${ }^{2}$ Al-Imâm al-Hââfizh al-Mujâhid Abî Ishâq Ibrâhîm ibn Mûsâ alGharnathî al-Syâthibî, al-Muwâfaqât fî̀ Ushûl al-A $\underline{h} k a \hat{a} m$, (Bayrût: Dâr al-Fikr, t.t.), h. 15 .
} 
tampaknya akan menjadi diskursus yang panjang dan berkelanjutan di masyarakat Indonesia, baik kalangan pakar hukum maupun kalangan umat Islam sendiri. Persoalan ini menjadi multikompleks mengingat pembahasan tentang hukum pidana erat kaitannya dengan aspek kehidupan, baik aspek politik, sosial, budaya, dan ekonomi.

Masykuri Abdillah memandang bahwa sejak masa reformasi, muncul aspirasi umat Islam yang variatif, baik dari kelompok ekslusif (fundamentalistik) hingga yang inklusif (liberalistik). ${ }^{3}$ Paling tidak ada tiga tanggapan seputar hukum pidana Nasional vis a vis hukum pidana Islam. Pertama, bahwa hukum pidana Nasional (positif) itu kompatibel dengan hukum pidana Islam, seperti tentang pelanggaran. Kedua, hukum pidana positif itu tidak bertentangan dengan hukum Islam, tetapi juga tidak sepenuhnya sama dengan hukum Islam, seperti tentang pencurian, pembunuhan, dan sebagainya. Ketiga, hukum pidana positif bertentangan dengan hukum (pidana) Islam, seperti hukum perzinaan dan minuman keras yang pelakunya hanya dapat dipidana jika merugikan pihak lain.

Berkenaan kaitan ini, 'Abd al-Qadîr 'Awdah memberikan tiga bentuk klasifikasi berkenaan dengan tujuan-tujuan dari syariah. Pertama, menjamin keamanan dan kebutuhan-kebutuhan hidup sebagai tujuan pertama dan utama (dharûriyyah). Kedua, menjamin kebutuhan-kebutuhan hidup yang bersifat sekunder (hâjiyâh). Dan ketiga, membuat perbaikanperbaikan bagi kehidupan masyarakat agar urusan sosial mereka lebih baik (tahsininiyyah). ${ }^{4}$

Dalam perspektif di atas, segala tindakan apapun yang dapat mengancam keselamatan masyarakat, termasuk juga lima hal pokok di atas, maka dianggap sebagai tindakan kejahatan yang bukan hanya dilarang agama, tetapi juga melanggar hukum.

\section{Sejarah Politik Hukum Indonesia}

Hukum Islam merupakan fase penting dalam sejarah hukum Indonesia, yang untuk kali pertama telah ada di Indonesia sebagai hukum positif. 5 Dalam tinjauan historis, praktik dan penerapan hukum Islam diIndonesia merupakan salah satu unsur dalam pembentukan hukum Nasional yang sejajar dengan hukum sipil Barat dan Adat. Antara ketiga hukum tersebut, yakni hukum

${ }^{3}$ Masykuri Abdillah, "Posisi Hukum Pidana Islam dalam Konteks Politik Hukum dan Perundangan Indonesia", makalah seminar Nasional Hukum Pidana Islam: Deskripsi, Analisis Perbandingan, dan Kritik Konstruktif, Fakultas Syariah IAIN Syarif Hidayatullah Jakarta, 22-23 Juni 1999, h. 7.

4 'Abd al-Qadîr 'Audah, Criminal Law of Islam, (Karachi: International Publisher, 1987), h. 246-249.

5 Moh. Idris Ramulyo, Asas-asas Hukum Islam (Jakarta: Sinar Grafika, 1995), h. 12.
Islam, Sipil, dan Adat, telah mengalami konflik yang panjang sejak masuknya Belanda ke Indonesia hingga saat ini. ${ }^{6}$ Hal ini berarti, dalam bahasa Bismar Siregar ${ }^{7}$, bahwa syariat Islam barulah diterima sebagai hukum positif apabila tidak bertentangan dengan hukum Adat. Teori ini lebih dikenal dengan teori receptie seperti yang dianut Snouck Hurgronje sebagai upaya pengebirian hukum Islam pada masa pra kemerdekaan. ${ }^{8}$

Sebelum Indonesia merdeka, syariat Islam sudah ada dan sudah populer. Hukum Islam secara menyeluruh pernah berkembang di wilayah Indonesia, yaitu ketika Indonesia masih terdiri atas pelbagai kerajaan, seperti Banten, Demak, Mataram, dan Samudera Pasai. ${ }^{9}$

Dalam kaitan ini tidak ada salahnya jika dikemukakan sedikit tentang latar belakang munculnya syariat Islam di Indonesia. Untuk membahas formalisasi syariat Islam, tampaknya diperlukan cuplikan latar belakang munculnya kata-kata syariat Islam di Indonesia. Terminologi ini muncul karena adanya suatu keyakinan bahwa "Islam adalah di atas dari segala-galanya". Islam diyakini menjadi solusi dari segala permasalahan yang muncul di permukaan. Imbasnya, mereka berusaha menjadikan hukum Islam sebagai hukum Publik. Sebagai negara berpenduduk Muslim terbesar di dunia, semangat menerapkan syariat wajar jika dimunculkan.

Menurut sejarah, yang sangat mungkin dapat dijadikan rujukan, terutama pada masa sejarah awal kemerdekaan kita, perjuangan kelompok Islam untuk memasukkan syariat begitu kuat mengemuka saat itu. Semangat yang muncul adalah menjadikan syariat sebagai bagian dari ideologi negara. ${ }^{10}$

Dalam perspektif politik hukum, kedudukan hukum Islam dalam sistem ketatanegaraan Indonesai, ${ }^{11}$ paling

\footnotetext{
${ }^{6}$ Khoiron Sirin, "Legislasi Hukum Islam di Indonesia: Sebuah Harapan-harapan Sosiologis", Jurnal al-Muqarin, no. 2/Th.IV/1998, h. 35 .

${ }^{7}$ Bismar Siregar, Hukum Acara Pidana, (Jakarta: Binacipta, 1983), cet. 1, h. 20-29.

${ }^{8}$ Abdul Rahmat AR, "Mempertimbangkan Hukum Pidana Islam dalam Proses Legislasi Hukum Nasional (Telaah Kritis Terhadap Efektifitas Pelaksanaan Sanksi Hukum Pidana Islam di Indonesia”, Tesis, Program Pascasarjana, IAIN Syarif Hidayatullah Jakarta, tahun 2002, h. 7.

${ }^{9}$ Lihat, Azyumardi Azra, Jaringan Global Lokal Islam Nusantara, (Bandung: Mizan, 2002), h. 19; lihat pula, Muhammad Daud Ali, "Kedudukan Hukum Islam dalam Sistem Hukum Nasional", dalam Taufik Abdullah dan Sharon Shiddiqie (ed.), Tradisi dan Kebangkitan Islam di Asia Tenggara, (Jakarta: LP3ES, 1989), h. 208.

${ }^{10}$ Kenyataan ini, secara tidak langsung, tidak dapat dipisahkan dari teori politik Islam yang selalu mengatur fungsi dan peran sebuah entitas umat Islam, yang perilaku mereka kerap terekam dalam adat setempat untuk menegakkan hukum dan keadilan. Lihat, Bambang Purnomo, "Menjalin Hukum Islam dalam Konsep Hukum Pidana Nasional", dalam Amrullah Ahmad SF, et. All., Dimensi Hukum Islam dalam Hukum Nasional, (Jakarta: Gema Insan Press, 1998), h. 157.

${ }^{11}$ Dalam perspektif ini, hukum Islam ditinjauan dari sumbernya terbagi menjadi dua, yaitu hukum Islam sebagai sumber persuasif (persuasive source), dan hukum Islam sebagai sumber otoritatif (authority
} 
tidak ada tiga alasan yang paling dominan. Pertama, pada sidang Badan Penyelidik Usaha-usaha Persiapan Kemerdekaan Indonesia (BPUPKI) yang dilakukan menjelang kemerdekaan Indonesia, selalu dibumbui perdebatan alot antara kaum nasionalis dengan wakil Islam tentang ketentuan memasukkan tambahan "tujuh kata" di sila pertama dari Pancasila, yakni "Ketuhanan Yang Maha Esa dengan kewajiban menjalankan syariat Islam bagi pemeluknya" sebagaimana tercantum dalam Jakarta Charter atau lebih dikenal dengan "Piagam Jakarta".

Kedua, pada sidang konstituante, torehan sejarah yang terjadi pascapemilu 1955, hal mana terjadi tarikmenarik antara kelompok Nasionalis dengan kelompok Islam. Tema perdebatan juga sama, yakni pro dan kontra seputar keinginan menjadikan syariat Islam sebagai bagian dari hukum Indonesia. Namun karena beberapa kali deadlock dan tidak jadinya rumusan Negara membuat Soekarno, sebagai Presiden Republik Indonesia, mengambil alih konstituante sehingga lahirlah Dekrit Presiden 5 Juli 1959. Perjuangan umat Islam, dengan demikian, kembali kandas.

Ketiga, seiring lamanya kendali Orde Baru yang dipimpin Soeharto, yang menabukan aspirasi, nuansa penerapan syariat Islam pun surut, meski tidak pernah pudar dari memori umat Islam. Pasca keruntuhan rezim Orde Baru, yang ditandai lahirnya Orde Reformasi, keinginan untuk mengamandemen Undang-undang Dasar dan memasukkan "tujuh kata" itu pun kembali muncul. Dalam pelbagai momentum sidang-sidang MPR yang mengagendakan amandemen UUD 1945, beberapa faksi Islam mencoba menghembuskan diskursus Piagam Jakarta. ${ }^{12}$

Menarik untuk mencermati alur perjalanan sejarah hukum Islam di tengah-tengah komunitas Islam terbesar di dunia itu. Pertanyaan-pertanyaan seperti seberapa jauh pengaruh sisi mayoritas Muslim Indonesia terhadap penerapan hukum Islam di Tanah Air? Maka dapat dijawab dengan memaparkan sejarah hukum Islam sejak komunitas Muslim hadir di Indonesia. Di samping itu, kajian tentang sejarah hukum Islam di Indonesia juga dapat dijadikan sebagai salah satu pijakan bagi umat Islam secara khusus untuk menentukan strategi yang tepat di masa depan dalam mendekatkan dan mengakrabkan bangsa ini dengan hukum Islam.

Proses sejarah hukum Islam yang diwarnai "benturan" dengan tradisi yang sebelumnya berlaku dan dengan

source). Lihat, Ismail Suny, "Kedudukan Hukum Islam dalam Sistem Ketatanegaraan Indonesia", dalam Amrullah Ahmad, dkk. (ed.), Dimensi Hukum Islam dalam Sistem Hukum Nasional (Jakarta: Gema Insani Press, 1996), 133.

${ }^{12}$ Lihat, Ibnu Hadjar, "Syari'at Islam dan Hukum Positif di Indonesia", diakses 28 November 2011); didapatkan dari http:// journal.uii.ac.id/index.php/JHI/article/viewFile/239/235. kebijakan-kebijakan politik, serta tindakan-tindakan yang diambil para tokoh Islam Indonesia terdahulu setidaknya dapat menjadi bahan telaah penting di masa datang. Paling tidak, sejarah itu menunjukkan bahwa proses Islamisasi sebuah masyarakat bukanlah proses yang dapat selesai seketika.

\section{Hukum Islam Masa Pra Penjajahan Belanda}

Daniel S. Lev mengatakan bahwa Islam telah membentuk sebuah konsepsi sosial politik supralokal sebelum penjajah Belanda dapat menyatukan Nusantara dalam sebuah administrasi pemerintahan (kolonialisme). ${ }^{13}$ Akar sejarah hukum Islam di kawasan nusantara menurut sebagian ahli sejarah dimulai pada abad pertama hijriyah, atau pada sekira abad ketujuh dan kedelapan masehi. Sebagai gerbang masuk ke dalam kawasan Nusantara, kawasan utara pulau Sumatera-lah yang kemudian dijadikan sebagai titik awal gerakan dakwah para pendatang muslim. Secara perlahan, gerakan dakwah itu kemudian membentuk masyarakat Islam pertama di Peureulak, Aceh Timur. Berkembangnya komunitas Muslim di wilayah itu kemudian diikuti oleh berdirinya kerajaan Islam pertama di Tanah air pada abad ketigabelas. Kerajaan ini dikenal dengan nama Samudera Pasai yang terletak di wilayah Aceh Utara. ${ }^{14}$

Kesultanan-kesultanan tersebut, sebagaimana tercatat dalam sejarah, menetapkan hukum Islam sebagai hukum positif atau hukum yang berlaku. Penetapan hukum Islam sebagai hukum positif di setiap kesultanan tersebut menguatkan pengamalannya yang memang telah berkembang di tengah masyarakat Muslim masa itu. Fakta-fakta ini dibuktikan dengan adanya literaturliteratur fikih yang ditulis oleh para ulama nusantara pada sekitar abad 16 dan 17. Dan kondisi terus berlangsung hingga para pedagang Belanda datang ke kawasan nusantara.

\section{Hukum Islam Masa Penjajahan Belanda}

Menurut Van den Berg, seperti dikutip Busthanul Arifin, berkesimpulan bahwa pada mulanya, orangorang Indonesia yang Muslim masih menerima dan memberlakukan hukum Islam secara keseluruhan, yang kemudian lebih dikenal dengan teori receptio in complexu. Pada masa-masa itu, Peradilan Agama

${ }^{13}$ Daniel S. Lev, Hukum dan Politik di Indonesia, (terj.), (Jakarta: LP3ES, 1990), h. 122-123.

${ }^{14}$ Pengaruh dakwah Islam yang cepat menyebar hingga ke pelbagai wilayah nusantara kemudian menyebabkan beberapa kerajaan Islam berdiri menyusul berdirinya Kerajaan Samudera Pasai di Aceh. Tidak jauh dari Aceh berdiri Kesultanan Malaka, lalu di pulau Jawa berdiri Kesultanan Demak, Mataram, dan Cirebon, kemudian di Sulawesi dan Maluku berdiri Kerajaan Gowa dan Kesultanan Ternate serta Tidore. 
memiliki kompetensi yang luas untuk memutuskan perkara-perkara yang masuk menurut hukum Islam, termasuk juga di dalamnya hukum pidana. ${ }^{15}$

Cikal bakal penjajahan Belanda terhadap kawasan Nusantara dimulai dengan kehadiran Organisasi Perdagangan Belanda di Hindia Timur, atau yang lebih dikenal dengan VOC. Sebagai organisasi dagang, VOC dapat dikatakan memiliki peran yang melebihi fungsinya. Hal ini sangat dimungkinkan sebab pemerintah kerajaan Belanda memang menjadikan VOC sebagai perpanjangan tangan di kawasan Hindia Timur. Karena itu di samping menjalankan fungsi perdagangan, VOC juga mewakili Kerajaan Belanda dalam menjalankan fungsi-fungsi pemerintahan, tentu dengan menggunakan hukum yang mereka bawa. ${ }^{16}$

Di Semarang, misalnya, hasil kompilasi itu dikenal dengan nama Kitab Hukum Mogharraer (dari alMubarrar). Namun kompilasi yang satu ini memiliki kelebihan dibanding Compendium Freijer, di mana ia juga memuat kaidah-kaidah hukum pidana Islam. Pengakuan terhadap hukum Islam ini terus berlangsung bahkan hingga menjelang peralihan kekuasaan dari Kerajaan Inggris kepada Kerajaan Belanda kembali.

Setelah Thomas Stanford Raffles menjabat Gubernur selama 5 tahun (1811-1816) dan Belanda kembali memegang kekuasaan terhadap wilayah Hindia Belanda, semakin tampak bahwa pihak Belanda berusaha keras mencengkramkan kuku-kuku kekuasaannya di wilayah ini. Namun upaya itu menemui kesulitan akibat adanya perbedaan agama antara penjajah dengan rakyat jajahannya, khususnya umat Islam yang mengenal konsep dâr al-Islâm dan dâr al-harb. Itulah sebabnya, Pemerintah Belanda mengupayakan beragam cara untuk menyelesaikan masalah itu, di antaranya dengan menyebarkan agama Kristen kepada rakyat pribumi dan membatasi keberlakuan hukum Islam hanya pada aspek-aspek batiniah (spiritual) saja. ${ }^{17}$

${ }^{15}$ Busthanul Arifin, Pelembagaan Hukum Islam di Indonesia: Akar Sejarah, Hambatan dan Prospeknya (Jakarta: Gema Insani Press, 1996), h. 35; lihat pula, Ropaun Rambe dan Mukri Agafi, Implementasi Hukum Islam (Jakarta: PT Perca, 2001), h. 2.

16 Dalam kenyataannya, penggunaan hukum Belanda itu menemukan kesulitan. Ini disebabkan karena penduduk pribumi berat menerima hukum-hukum yang asing bagi mereka. Akibatnya, VOC pun membebaskan penduduk pribumi untuk menjalankan apa yang selama ini telah mereka jalankan. Kaitannya dengan hukum Islam, dapat dicatat beberapa "kompromi" yang dilakukan oleh pihak VOC, yaitu dalam Statuta Batavia yag ditetapkan pada 1642 oleh VOC, dinyatakan bahwa hukum kewarisan Islam berlaku bagi para pemeluk agama Islam. Adanya upaya kompilasi hukum kekeluargaan Islam yang telah berlaku di tengah masyarakat. Upaya ini diselesaikan pada 1760. Kompilasi ini kemudian dikenal dengan Compendium Freijer. Adanya upaya kompilasi serupa di pelbagai wilayah lain, seperti di Semarang, Cirebon, Gowa, dan Bone. Busthanul Arifin, Pelembagaan Hukum Islam di Indonesia, h. 36

${ }^{17}$ Pelaksanaan hukum Islam, yang selama ini hidup di tengah-
Upaya pembatasan keberlakuan hukum Islam oleh Pemerintah Hindia Belanda secara kronologis sebagai berikut: Pertama, pada pertengahan abad XIX, Pemerintah Hindia Belanda melaksanakan Politik Hukum $^{18}$ yang sadar, yaitu kebijakan yang secara sadar ingin menata kembali dan mengubah kehidupan hukum di Indonesia dengan hukum Belanda. Atas dasar nota yang disampaikan Scholten van Oud Haarlem, Pemerintah Belanda menginstruksikan penggunaan undang-undang agama, lembaga-lembaga, dan kebiasaan pribumi dalam hal persengketaan yang terjadi di antara mereka, selama tidak bertentangan dengan asas kepatutan dan keadilan yang diakui umum. Klausul terakhir ini kemudian menempatkan hukum Islam di bawah subordinasi hukum Belanda. ${ }^{19}$

Kedua, pada 1925, dilakukan perubahan terhadap Pasal 134 ayat (2) Indische Staatsregeling (yang isinya sama dengan Pasal 78 Regerringsreglement), yang intinya perkara perdata sesama muslim akan diselesaikan dengan hakim agama Islam jika hal itu telah diterima oleh hukum Adat dan tidak ditentukan lain oleh suatu ordonansi. Lemahnya posisi hukum Islam ini terus terjadi hingga menjelang berakhirnya kekuasaan Hindia Belanda di wilayah Indonesia pada 1942.

\section{Hukum Islam Masa Pendudukan Jepang}

Pada zaman pendudukan Jepang yang berlangsung selama 3,5 tahun, bisa dikatakan tidak ada perubahan politik hukum pemerintah terhadap hukum Islam. Kalaupun ada, mereka hanya memanfaatkan hukum Islam untuk mengambil hati penduduk muslim Indonesia. ${ }^{20}$ Setelah Jenderal Ter Poorten menyatakan

tengah masyarakat Islam di masa kolonialisme, masa kerajaan, secara perlahan namun pasti, terus dibungkam oleh penjajah, melalui sejumlah politik hukumnya, khususnya yang berkenaan dengan hukum Islam yang bersifat yuridis (qadhẩi). lihat, Rifyal Ka'bah, "Reformasi Metodologi Pengembangan Hukum Islam”, dalam Mimbar Hukum: Aktualisasi Hukum Islam, no. 34, tahun X 1999, h. 46.

${ }^{18}$ Dalam politik hukum, di antaranya Belanda memanfaatkan hukum adat yang ditempatkan melebihi hukum Islam, atau lebih dikenal dengan teori resepsi. Sehingga, berlakulah keadaan di mana hukum Islam tidak dengan serta merta dapat diakui Negara sebelum teresepsi oleh hukum Adat. Keadaan ini, oleh Bismar Siregar diistilahkan dengan Tuhan yang beradat, atau istilah Hazairin disebut "teori Iblis", yang telah menjauhkan umat Islam dengan hukum agamanya sendiri. Inilah kelihaian penjajah dalam mengebiri hukum Islam pada masa pra kemerdekaan. Lihat, Bismar Siregar, Hukum Acara Pidana (Jakarta: Bina Cipta, 1987), h. 28.

${ }^{19}$ Atas dasar teori resepsi yang dikeluarkan oleh Snouck Hurgronje, Pemerintah Hindia Belanda pada 1922 kemudian membentuk komisi untuk meninjau ulang wewenang pengadilan agama di Jawa dalam memeriksa kasus-kasus kewarisan (dengan alasan, ia belum diterima oleh hukum adat setempat).

${ }^{20}$ Busthanul Arifin, "Pikiran-pikiran tentang Hukum Pidana Kita", Makalah seminar Nasional Hukum Pidana Islam: Deskripsi, Analisis Perbandingan dan Kritik Konstruktif, Jakarta, IAIN Syarif Hidayatullah Jakarta, 22-23 Juni 1999, h. 12. 
menyerah tanpa syarat kepada panglima militer Jepang untuk kawasan Selatan pada 8 Maret 1942, segera Pemerintah Jepang mengeluarkan pelbagai peraturan. ${ }^{21}$

Meskipun demikian, Pemerintah Pendudukan Jepang tetap melakukan pelbagai kebijakan untuk menarik simpati umat Islam di Indonesia. Antara: (1) Janji Panglima Militer Jepang untuk melindungi dan memajukan Islam sebagai agama mayoritas penduduk pulau Jawa; (2) mendirikan Shumubu (Kantor Urusan Agama Islam) yang dipimpin oleh bangsa Indonesia sendiri; (3) Mengizinkan berdirinya ormas Islam, seperti Muhammadiyah dan NU; (4) Menyetujui berdirinya Majelis Syura Muslimin Indonesia (Masyumi) pada Oktober 1943; dan (5) Menyetujui berdirinya Hizbullah sebagai pasukan cadangan yang mendampingi berdirinya PETA. ${ }^{22}$

Dengan demikian, nyaris tidak ada perubahan berarti bagi posisi hukum Islam selama masa pendudukan Jepang di tanah air. Namun bagaimanapun juga, masa pendudukan Jepang lebih baik daripada Belanda, terutama dari sisi adanya pengalaman baru bagi para pemimpin Islam dalam mengatur masalah-masalah keagamaan. Abikusno Tjokrosujoso menyatakan bahwa kebijakan pemerintah Belanda telah memperlemah posisi Islam. Islam tidak memiliki pegawai di bidang agama yang terlatih di masjid-masjid atau pengadilanpengadilan Islam. Belanda menjalankan kebijakan politik yang memperlemah posisi Islam. Ketika pasukan Jepang datang, mereka menyadari bahwa Islam adalah suatu kekuatan di Indonesia yang dapat dimanfaatkan.

\section{Hukum Islam Masa Kemerdekaan}

Meskipun Pendudukan Jepang memberikan banyak pengalaman baru kepada para pemuka Islam Indonesia, namun pada akhirnya, seiring dengan semakin lemahnya langkah strategis Jepang memenangkan perang yang kemudian membuat mereka membuka lebar jalan untuk kemerdekaan Indonesia, Jepang mulai mengubah arah kebijakannya. Mereka mulai "melirik" dan memberi dukungan kepada para tokoh nasionalis Indonesia. Dalam hal ini, tampaknya Jepang lebih memercayai kelompok nasionalis untuk memimpin Indonesia masa

${ }^{21}$ Salah satu di antaranya adalah Undang-Undang Nomor 1 Tahun 1942, yang menegaskan bahwa Pemerintah Jepang meneruskan segala kekuasaan yang sebelumnya dipegang oleh Gubernur Jenderal Hindia Belanda. Ketetapan baru ini tentu saja berimplikasi pada tetapnya posisi keberlakuan hukum Islam sebagaimana kondisi terakhirnya di masa pendudukan Belanda.

22 Berupaya memenuhi desakan para tokoh Islam untuk mengembalikan kewenangan Pengadilan Agama dengan meminta seorang ahli hukum Adat, Soepomo, pada Januari 1944 untuk menyampaikan laporan tentang hal itu. Namun upaya ini kemudian "dimentahkan" oleh Soepomo dengan alasan kompleksitas dan menundanya hingga Indonesia merdeka. depan. Maka tidak mengherankan jika beberapa badan dan komite negara, seperti Dewan Penasihat (Sanyo Kaigi) dan BPUPKI (Dokuritsu Zyunbi Tyoosakai) kemudian diserahkan kepada kubu nasionalis.

Hingga Mei 1945, komite yang terdiri atas 62 orang ini, paling hanya 11 di antaranya yang mewakili kelompok Islam. Atas dasar itulah, BPUPKI bukanlah badan yang dibentuk atas dasar pemilihan yang demokratis, meskipun Soekarno dan Mohammad Hatta berusaha agar anggota Badan ini cukup representatif mewakili pelbagai golongan dalam masyarakat Indonesia.

Secara konkret, setelah Indonesia merdeka, upaya untuk melakukan pembaruan hukum pidana terus berlangsung. Upaya yang sistematis dalam rangka mengganti KUHP warisan Hindia Belanda dengan kitab undang-undang yang lebih sesuai dengan falsafah hidup bangsa Indonesia dan kesadaran hukum masyarakat Indonesia, tidak putus-putus dilakukan. Bahkan sebagian besar produk hukum pidana materiil sejak 1946 hingga 1947, pada dasarnya menggambarkan adanya usaha mengarah ke sana. ${ }^{23}$

Perdebatan panjang tentang dasar negara di BPUPKI kemudian berakhir dengan lahirnya apa yang disebut dengan "Piagam Jakarta". Kalimat kompromi yang paling penting dalam Piagam Jakarta terutama ada pada kalimat "Negara berdasar atas Ketuhanan dengan kewajiban menjalankan syariat Islam bagi pemelukpemeluknya". ${ }^{24}$ Menurut Muhammad Yamin, kalimat ini menjadikan Indonesia merdeka bukan sebagai negara sekuler dan bukan pula negara Islam. ${ }^{25}$

Ada banyak kabut berkenaan dengan penyebab hal itu. Tapi semua versi mengarah kepada Mohammad Hatta yang menyampaikan keberatan golongan Kristen di Indonesia Timur. Hatta mengatakan ia mendapat informasi tersebut dari seorang opsir angkatan laut Jepang pada sore hari 17 Agustus 1945. Namun Letkol Shegeta Nishijima satu-satunya opsir AL Jepang yang ditemui Hatta pada saat itu menyangkal hal tersebut.

${ }^{23}$ Jimliy Asshiddiqie, Pembaharuan Hukum Islam, (Bandung: Aksara, 1996), h. 19-22.

${ }^{24}$ Lahirnya Piagam Jakarta sebagai rumusan pertama Mukadimah UUD 1945 atau rumusan pertama Pancasila ini adalah hasil dari perjuangan panjang politik para ulama Islam terkemuka. Rumusan Piagam Jakarta ini juga yang kemudian oleh banyak kalangan dianggap sebagai ide dasar perjuangan pemberlakuan syariat Islam di Indonesia saat ini. Lihat lebih lanjut, "Formalisasi Pidana Islam di Indonesia: Analisis Kasus Peneraan Hukum Pidana Islam di Nanggroe Aceh Darussalam”, Tesis Sekolah Pascasarjana UIN Syarif Hidayatullah Jakarta, 2009, h. 84.

${ }^{25}$ Dengan rumusan semacam ini sesungguhnya lahir sebuah implikasi yang mengharuskan adanya pembentukan undang-undang untuk melaksanakan syariat Islam bagi para pemeluknya. Tetapi rumusan kompromis Piagam Jakarta itu akhirnya gagal ditetapkan saat akan disahkan pada 18 Agustus 1945 oleh PPKI. "Formalisasi Pidana Islam di Indonesia, h. 85. 
Ia bahkan menyebutkan justru Latuharhary yang menyampaikan keberatan itu. Keseriusan tuntutan itu sejatinya perlu dipertanyakan mengingat Latuharhary bersama dengan Maramis, seorang tokoh Kristen dari Indonesia Timur lainnya, telah menyetujui rumusan kompromi itu saat sidang BPUPKI.

Pada akhirnya, di periode ini, status hukum Islam tetaplah samar-samar. Isa Anshary mengatakan, kejadian mencolok mata sejarah ini dirasakan oleh umat Islam sebagai suatu 'permainan sulap' yang masih diliputi kabut rahasia suatu politik pengepungan kepada cita-cita umat Islam.

\section{Hukum Islam Masa Kemerdekaan}

Selama hampir lima tahun setelah proklamasi kemerdekaan, Indonesia memasuki masa-masa revolusi (1945-1950). Menyusul kekalahan Jepang oleh tentara-tentara sekutu, Belanda ingin kembali menduduki kepulauan Nusantara. Dari beberapa pertempuran, Belanda berhasil menguasai beberapa wilayah Indonesia, di mana ia kemudian mendirikan negara-negara kecil yang dimaksudkan untuk mengepung Republik Indonesia. Pelbagai perundingan dan perjanjian kemudian dilakukan, hingga akhirnya tidak lama setelah Linggarjati, lahirlah apa yang disebut dengan Konstitusi Indonesia Serikat pada 27 Desember 1949.

Dengan berlakunya Konstitusi RIS tersebut, maka UUD 1945 dinyatakan berlaku sebagai konstitusi Republik Indonesia yang merupakan satu dari 16 bagian negara Republik Indonesia Serikat. Konstitusi RIS sendiri jika ditelaah, sangat sulit untuk dikatakan sebagai konstitusi yang menampung aspirasi hukum Islam. Mukadimah Konstitusi ini, misalnya, sama sekali tidak menegaskan posisi hukum Islam sebagaimana rancangan UUD 1945 yang disepakati oleh BPUPKI. Demikian pula dengan batang tubuhnya, yang bahkan dipengaruhi oleh paham liberal yang berkembang di Amerika dan Eropa Barat, serta rumusan Deklarasi HAM versi PBB.

Namun saat negara bagian RIS pada awal 1950 hanya tersisa tiga negara saja, negara Sumatera Timur, dan negara Indonesia Timur, salah seorang tokoh umat Islam, Muhammad Natsir, mengajukan apa yang kemudian dikenal sebagai "Mosi Integral Natsir" sebagai upaya untuk melebur ketiga negara bagian tersebut. Akhirnya, pada 19 Mei 1950, semuanya sepakat membentuk kembali Negara Kesatuan Republik Indonesia berdasarkan Proklamasi 1945. Dan dengan demikian, Konstitusi RIS dinyatakan tidak berlaku, digantikan dengan UUD Sementara (UUDS) 1950.

Jika dikaitkan dengan hukum Islam, perubahan ini tidaklah membawa dampak yang signifikan. Sebab, ketidakjelasan posisinya masih ditemukan, baik dalam Mukadimah maupun batang tubuh UUDS $1950,{ }^{26}$ kecuali pada pasal 34 yang rumusannya sama dengan pasal 29 UUD 1945, bahwa "Negara berdasar Ketuhanan yang Maha Esa" dan jaminan negara terhadap kebebasan setiap penduduk menjalankan agamanya masing-masing. Juga pada pasal 43 yang menunjukkan keterlibatan negara dalam urusan-urusan keagamaan. Kelebihan lain dari UUDS 1950 ini adalah terbukanya peluang untuk merumuskan hukum Islam dalam wujud peraturan dan undang-undang. Peluang ini ditemukan dalam ketentuan pasal 102 UUDS 1950. Peluang inipun sempat dimanfaatkan oleh wakil-wakil umat Islam saat mengajukan rancangan undang-undang tentang perkawinan umat Islam pada 1954. Meskipun upaya ini kemudian gagal akibat "hadangan" kaum nasionalis yang juga mengajukan rancangan Undang-undang Perkawinan Nasional. Dan setelah itu, semua tokoh politik kemudian nyaris tidak lagi memikirkan pembuatan materi undang-undang baru, karena konsentrasi mereka tertuju pada bagaimana mengganti UUDS 1950 itu dengan undang-undang yang bersifat tetap.

Hal penting terkait dengan hukum Islam dalam peristiwa Dekrit ini adalah konsiderannya yang menyatakan bahwa "Piagam Jakarta tertanggal 22 Juni menjiwai UUD 1945" dan merupakan "suatu kesatuan dengan konstitusi tersebut". Hal ini tentu saja mengangkat dan memperjelas posisi hukum Islam dalam UUD, bahkan menurut Anwar Harjono lebih dari sekadar "dokumen historis".

Namun bagaimana dalam tataran aplikasi? Lagilagi faktor-faktor politik adalah penentu utama dalam hal ini. Pengejawantahan kesimpulan akademis ini hanya sekadar menjadi wacana jika tidak didukung oleh daya tawar politik yang kuat dan meyakinkan. Hal lain yang patut dicatat di sini adalah terjadinya beberapa pemberontakan yang "bernuansa" Islam. Yang paling fenomenal adalah gerakan DI/TII dipelopori oleh Kartosuwirjo dari Jawa Barat.

26 Perjuangan mengganti UUD Sementara itu kemudian diwujudkan dalam Pemilihan Umum untuk memilih dan membentuk Majelis Konstituante pada akhir 1955. Majelis yang terdiri atas 514 orang itu kemudian dilantik oleh Presiden Soekarno pada 10 November 1956. Namun delapan bulan sebelum batas akhir masa kerjanya, Majelis ini dibubarkan melalui Dekrit Presiden yang dikeluarkan pada 5 Juli 1959. 
Kartosuwirjo sesungguhnya telah memproklamasikan negara Islamnya pada 14 Agustus 1945, atau dua hari sebelum proklamasi kemerdekaan Indonesia pada 17 Agustus 1945. Namun ia melepaskan aspirasinyauntuk kemudian bergabung dengan Republik Indonesia. Tetapi ketika kontrol RI terhadap wilayahnya semakin merosot akibat agresi Belanda, terutama setelah diproklamasikannya Negara boneka Pasundan di bawah kontrol Belanda, ia pun memproklamasikan berdirinya Negara Islam Indonesia pada 1948. ${ }^{27}$

\section{Hukum Islam Era Orde Lama dan Orde Baru}

Mungkin tidak terlalu keliru jika dikatakan bahwa Orde Lama adalah eranya kaum nasionalis dan komunis. Sementara kaum muslim di era ini perlu sedikit merunduk dalam memperjuangkan citacitanya. Salah satu partai yang mewakili aspirasi umat Islam kala itu, Masyumi, harus dibubarkan pada 15 Agustus 1960 oleh Soekarno, dengan alasan tokohtokohnya terlibat pemberontakan (PRRI di Sumatera Barat). Sementara NU_yang kemudian menerima Manipol Usdek-nya Soekarno-bersama dengan PKI dan PNI kemudian menyusun komposisi DPR Gotong Royong yang berjiwa Nasakom. ${ }^{28}$

Menyusul gagalnya kudeta PKI pada 1965 dan berkuasanya Orde Baru, banyak pemimpin Islam Indonesia yang sempat menaruh harapan besar dalam upaya politik mereka mendudukkan Islam sebagaimana mestinya dalam tatanan politik maupun hukum di Indonesia. Apalagi kemudian Orde Baru membebaskan bekas tokoh-tokoh Masyumi yang sebelumnya dipenjara oleh Soekarno. Namun, segera saja Orde ini menegaskan perannya sebagai pembela Pancasila dan UUD 1945. Bahkan di awal 1967, Soeharto menegaskan bahwa militer tidak akan menyetujui upaya rehabilitasi kembali partai Masyumi. Lalu bagaimana dengan hukum Islam?

27 Pemicu konflik yang berakhir pada 1962 dan mencatat 25.000 korban tewas itu. Menurut sebagian peneliti, lebih banyak diakibatkan oleh kekecewaan Kartosuwirjo terhadap strategi para pemimpin pusat dalam mempertahankan diri dari upaya pendudukan Belanda kembali, dan bukan atas dasar apa yang mereka sebut dengan "kesadaran teologis-politis"nya.

28 Berdasarkan itu, terbentuklah MPRS yang kemudian menghasilkan dua ketetapan, salah satunya adalah tentang upaya unifikasi hukum yang harus memperhatikan kenyataan-kenyataan umum yang hidup di Indonesia. Meskipun hukum Islam adalah salah satu kenyataan umum yang selama ini hidup di Indonesia, dan atas dasar itu Tap MPRS tersebut membuka peluang untuk memosisikan hukum Islam sebagaimana mestinya. Namun lagi-lagi ketidakjelasan batasan "perhatian" itu membuat hal ini semakin kabur. Dan peran hukum Islam di era inipun kembali tidak mendapatkan tempat yang semestinya.
Meskipun kedudukan hukum Islam sebagai salah satu sumber hukum Nasional tidak begitu tegas di masa awal Orde ini, namun upaya-upaya untuk mempertegasnya tetap terus dilakukan. Hal ini ditunjukkan oleh Mohammad Dahlan, seorang Menteri Agama dari kalangan NU, yang mencoba mengajukan Rancangan Undang-undang Perkawinan Umat Islam dengan dukungan kuat fraksi-fraksi Islam di DPR-GR. Meski gagal, upaya ini kemudian dilanjutkan dengan mengajukan rancangan hukum formil yang mengatur lembaga peradilan di Indonesia pada 1970. Upaya ini kemudian membuahkan hasil dengan lahirnya UU No. 14/1970, yang mengakui Pengadilan Agama sebagai salah satu badan peradilan yang berinduk pada Mahkamah Agung. Dengan UU ini, menurut Hazairin, dengan sendirinya hukum Islam telah berlaku secara langsung sebagai hukum yang berdiri sendiri. ${ }^{29}$

\section{Hukum Islam Era Reformasi}

Pasca runtuhnya kekuasaan Soeharto, demokrasi dan kebebasan bergemuruh di seluruh pelosok Indonesia. Setelah melalui perjalanan panjang, perlahan tapi pasti, di era ini setidaknya hukum Islam mulai menempati posisinya. Lahirnya Ketetapan MPR No. III/MPR/2000 tentang Sumber Hukum dan Tata Urutan Peraturan Perundang-undangan semakin membuka peluang lahirnya aturan undangundang yang berlandaskan hukum Islam. Terutama pada Pasal 2 ayat (7) yang menegaskan ditampungnya peraturan daerah yang didasarkan pada kondisi khusus dari suatu daerah di Indonesia, dan bahwa peraturan itu dapat menyampingkan berlakunya suatu peraturan yang bersifat umum.

Lebih dari itu, di samping peluang yang semakin jelas, upaya konkret merealisasikan hukum Islam dalam wujud undang-undang dan peraturan telah membuahkan hasil yang nyata di era ini. Salah satu buktinya adalah Undang-undang Nomor 32 Tahun 2004 dan Kanun Provinsi Nangroe Aceh Darussalam tentang Pelaksanaan Syariat Islam Nomor 11 Tahun 2002. Dengan demikian, di era reformasi ini, terbuka peluang yang luas bagi sistem hukum Islam untuk memperkaya khazanah tradisi hukum di Indonesia.

${ }^{29}$ Penegasan terhadap berlakunya hukum Islam semakin jelas ketika UU No. 7 Tahun 1989 tentang Peradilan Agama ditetapkan. Hal ini kemudian disusul dengan usaha-usaha intensif untuk mengompilasikan hukum Islam di bidang-bidang tertentu. Dan upaya ini membuahkan hasil pada Februari 1988, Soeharto sebagai Presiden menerima hasil kompilasi itu dan menginstruksikan penyebarluasannya kepada Menteri Agama. 
Kita dapat melakukan langkah-langkah pembaruan dan bahkan pembentukan hukum baru yang bersumber dan berlandaskan sistem hukum Islam, untuk kemudian dijadikan sebagai norma hukum positif yang berlaku dalam hukum Nasional kita.

Di era reformasi, kebijakan hukum pidana (jinâyah) mengalami perkembangan, terutama sejak adanya otonomiasi daerah. Di masa reformasi ini dapat dikatakan bahwa secara politis-yuridis telah mengalami kemajuan dengan adanya keberpihakan pemerintah terhadap umat Islam untuk melegalisasi syariat Islam menjadi hukum Nasional, walaupun masih sebatas di wilayah hukum privat yang berkenaan dengan 'ubûdiyyah dan mu'âmalah (perdata Islam).

Peraturan dan perundang-undangan yang menjadi bagian dari hukum Nasional pada masa Orde Baru, yaitu undang-undang No. 1 Tahun 1974 tentang Perkawinan. Sedangkan pada masa reformasi telah lahir Undang-undang No. 10 Tahun 1998 tentang Perubahan atas Undang-undang No. 7 Tahun 1992 tentang Perbankan. Demikian juga telah dilegislasinya peraturan dan Perundang-undangan Islam yang menjadi hukum positif, yakni Kompilasi Hukum Islam, Undang-undang No. 17 Tahun 1999 tentang Penyelenggaraan Ibadah Haji, dan Undang-undang No. 38 Tahun 1999 tentang Pengelolaan Zakat, Undang-undang tentang Perbankan Syariah, dan sebagainya. Keberhasilan perjuangan umat Islam secara yuridis dalam melakukan formalisasi syariat Islam menjadi bagian hukum Nasional atau menjadi hukum positif tersebut, sesungguhnya tidak terlepas dari tuntutan akidah yang menjadi kewajiban bagi umat Islam untuk menegakkan khilâfah dan imâmah dalam menjalankan syariat Islam secara kâffah di mana, kapan, bagaimana, dan oleh siapa pun tanpa dibatasi oleh paham apapun. ${ }^{30}$

\section{Formalisasi Hukum Pidana Islam}

Formalisasi syariat Islam dalam beberapa perspektif tatahukum Indonesiaternyatasangat dirasa rumit, karena berkaitan dengan pelbagai aspek historis, ideologis, politis, yuridis, religius, sosiologis, dan kultural, baik dilingkup nasional maupun internasional. Aspek-aspek tersebut dalam realitasnya ternyata tidak berdiri sendiri, melainkan saling memengaruhi satu dengan yang lainnya. Oleh sebab itu, proses formalisasi syariat Islam dalam tata hukum di Indonesia memerlukan waktu yang sangat panjang, melintasi beberapa periode dan generasi

\footnotetext{
${ }^{30}$ Sebagaimana umat Islam Indonesia terus bergerak, berjuang, dan berjihad dengan mengorbankan apa saja hingga menemui ajal kematian menjadi syuhada untuk menegakkan dan menerapkan agamanya. Secara sosiologis, keberhasilan itu juga tidak terlepas dari gerakan masyarakat Indonesia, khususnya umat Islam, sejak dulu hingga saat ini yang tidak mengenal lelah dan putus asa.
}

serta memunculkan problematika yang amat krusial. Jelasnya, melalui formalisasi dan legislasi, hukum Islam telah bergeser dari otoritas hukum agama (devin law) menjadi otoritas hukum negara (state law). ${ }^{31}$

Hukum Islam merupakan doktrin Islam yang paling inti dari keseluruhan ajaran-ajaran Islam lainnya. ${ }^{32}$ Karena hukum Islam tidak saja dipandang sebagai suatu aturan yang membimbing perilaku keagamaan umat Muslim, tetapi juga merupakan penjelmaan konkret kehendak Allah di tengah-tengah masyarakat. Namun demikian, hukum Islam tumbuh dan berkembang dalam pelbagai situasi dan kondisi serta aspek ruang dan waktu, sebagaimana disiplin keilmuan lainnya. Berkembangnya hukum Islam di masyarakat merupakan konsekuensi logis dari pertemuannya dengan faktafakta sosial, dan inilah kemudian yang melahirkan epistemologi hukum Islam (fikih). ${ }^{33}$

Fikih merupakan terminologi baku sebagai sebutan salah satu cabang keilmuan dalam Islam. Pemaknaan paling mendasar dari istilah tersebut adalah pemahaman seorang mujtahid terhadap teks-teks agama (Alquran dan Hadis) dalam interaksinya dengan realitas-realitas yang berkembang. ${ }^{34}$ Pemahaman ini diperlukan sebelum muatan teks tersebut dilaksanakan. Tujuannya untuk mempertegas kesesuaian antara maksud yang diinginkan oleh sang "pembicara" teks (al-mutakallim), makna menurut sang penerima teks (al-mutalaqqi) dan konstruksi bahasa yang digunakannya (al-uslûb allughawî). Karena itu, Ibn al-Qayyim menyatakan:

"Fikih itu lebih dalam dari sekadar pemahaman terhadap makna, ia merupakan pemahaman terhadap keinginan sang Pembicara dari susunan kalimatnya. Ini tentu memiliki kadar yang lebih dari sekadar konstruksi lafal dalam ilmu bahasa. Perbedaan manusia dalam mencerna hal ini akan mengakibatkan perbedaan mereka dalam hal fikih dan pemahaman terhadap agama". ${ }^{35}$

Adapun hukum Islam biasanya disebut dengan beberapa istilah ${ }^{36}$ atau nama yang masing-masing menggambarkan sisi atau karakteristik tertentu hukum tersebut. Setidaknya ada empat nama yang sering

${ }^{31}$ Muhammad Tahir Azhari, Negara Hukum: Suatu Studi tentang Prinsip-prinsipnya Dilihat dari Segi Hukum Islam, Implrmrntasinya pada Periode Negara Madinah dan Masa Kini (Jakarta: Bulan Bintang, 1992), h. 43.

32 Joseph Schatch, An Introduction to Islamic Law (London: Calender, 1996), h.1.

${ }^{33}$ Mûsâ Kâmil, al-Madkhal ilâ Tasyrî̀ al-Islâmî (Bayrût: Mu’assasah al-Risâlah, t.th), h. 89; Lihat pula, Abû Ishâa al-Shîrâzî, al-Lumẩ fî̀ Ushûl al-Fiqh, (Libanon: Dâr al-Kutub, 475 H), h. 6.

${ }^{34}$ Muhammad al-Dasûqi dan Amînah al-Jabir, Muqaddimah $f i$ Dirâsah al-Figh al-Islâmî (Qatar: Dawhah, 1990), h. 13-22.

${ }^{35}$ Ibn al-Qayyim al-Jawziyyah, I'làm al-Muwaqqi în, dalam 'Abd al-Ra'ûf Sa'dan (ed.) (Ttp. Maktabah al-Kulliyah al-Azhariyyah, t.th.), $1: 219$.

${ }^{36}$ Mustofa, Hukum Islam Kontemporer (Jakarta: Sinar Grafika, 2003), h. 1. 
dikaitkan kepada hukum Islam yakni: syariah, fikih, hukum syarak, dan kanun. Syariah biasanya dipakai dalam dua pengertian: dalam arti luas dan dalam arti sempit. Dalam arti luas, syariah merujuk kepada himpunan norma atau petunjuk yang bersumber kepada wahyu Ilahi untuk mengatur sistem kepercayaan dan tingkah laku konkret manusia dalam pelbagai dimensi hubungan. Dengan demikian, syariah dalam hal ini meliputi dua aspek agama Islam, yaitu akidah dan amaliah.

Aspek amaliah dari syariah dalam arti luas sering disebut syariah juga, yakni syariah dalam arti sempit yang merujuk kepada himpunan norma yang bersumber kepada wahyu Ilahi yang mengatur tingkah laku konkret manusia dalam pelbagai dimensi hubungannya. Dengan demikian, syariah dalam arti sempit merupakan bagian dari syariah dalam arti luas. Syariah dalam arti sempit inilah yang biasanya disebut hukum, yaitu hukum Islam. Namun, konsep syariah dalam arti sempit ini tidaklah persis sama dengan konsep hukum, karena syariah (dalam arti sempit) tidak memuat kaidah hukum an sich yang didukung oleh sanksi yang dapat ditegakkan secara paksa, tetapi meliputi pula kaidah keagamaan, kesusilaan, dan sosial. Dengan begitu, konsepsi hukum dalam perspektif Islam lebih luas dari apa yang biasanya kita kenal sebagai hukum yang dibatasi pada kaidah yang didukung oleh sanksi yang dapat ditegakkan secara paksa oleh kekuasaan yang berwenang.

Fikih adalah istilah lain yang digunakan untuk menyebut hukum Islam. Istilah ini biasanya dipakai dalam dua arti. Pertama, dalam arti ilmu hukum atau paralel dengan istilah Islamicjurisprudence dalam bahasa Inggeris, sehingga dengan demikian fikih merujuk kepada pengertian cabang studi yang mengkaji hukum Islam. Kedua, digunakan dalam arti hukum itu sendiri dan paralel dengan istilah law dalam bahasa Inggris. Dalam arti fikih merupakan himpunan norma atau aturan yang mengatur tingkah laku, baik berasal langsung dari Alquran dan Sunah Nabi Saw. maupun dari hasil ijtihad para ahli hukum Islam. Umumnya dalam praktik, fikih dalam arti kedua ini dipakai secara identik dengan syariah dalam arti sempit. Perbedaannya hanya pada sisi penekanan di mana syariah menggambarkan dan menekankan bahwa hukum Islam berdimensi Ilahi dan bersumber kepada wahyu Allah. Sedangkan fikih menggambarkan karakteristik lain dari hukum Islam, yaitu meskipun berkarakter Ilahiah, penerapan dan penjabarannya dalam kehidupan riil dan konkret masyarakat sepenuhnya merupakan upaya manusiawi. ${ }^{37}$

Hukum syarak merujuk kepada satuan norma atau

\footnotetext{
${ }^{37}$ Akhmad Zaki Yamani, Syariat Islam yang Abadi Menjawab Tantangan Masa Kini, terj. Mahyuddin Syafii, (Bandung: Al-Ma’arif. 1986), h. 17.
}

kaidah. Himpunan norma atau hukum syarak ini membentuksyariah atau fikih. Norma atau hukum syarak yang membentuk syariah atau fikih ini meliputi norma-

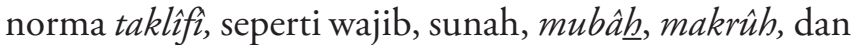
haram, maupun meliputi norma-norma wadh 'î seperti "sebab" (akad merupakan sebab terjadinya perpindahan milik atas suatu barang yang diperjualbelikan), syarat (milik sendiri adalah syarat untuk sahnya wakaf), dan penghalang (delik pembunuhan menjadi penghalang bagi pelakunya untuk mendapatkan warisan atau wasiat dari pewaris atau pemberi wasiat yang dibunuhnya).

Kanun menggambarkan bagian dari syariah yang telah dipositivisasi dan diintegrasikan oleh pemerintah menjadi hukum negara, seperti hukum perkawinan (UU No. 1 Tahun 1974), hukum wakaf (UUNo. 41 Tahun 2004), dan lain-lain. Selain itu, kanun juga merujuk kepada pelbagai peraturan perundangan yang dikeluarkan oleh Pemerintah di negeri Muslim dalam rangka pelaksanaan syariah dan mengisi kekosongan serta melengkapi syariah. Tindakan ini disebut siyâsah syar'iyyah. ${ }^{38}$

Istilah-istilah ini memperlihatkan strategi dan taktik hukum Islam untuk terus berevolusi mengikuti perkembangan dan perubahan zaman dengan tetap mempertahankan ciri esensialnya sebagai hukum yang berdimensi dan bersumber Ilahi. Sepanjang sejarahnya, hukum Islam senantiasa menjadi hukum yang berlaku dalam masyarakat muslim. Di Indonesia, hukum Islam merupakan salah satu sumber pengembangan hukum Nasional, di samping hukum adat dan hukum Barat. Dalam tata hukum Indonesia, hukum Islam memiliki peluang konstitusional yang jelas. Menurut Hazairin, pasal-pasal UUD 1945 mengandung prinsipprinsip, antara lain tidak boleh dibuat peraturan yang bertentangan dengan kaidah-kaidah agama dan negara berkewajiban menjalankan syariat agama-agama, yaitu syariat Islam bagi umat Islam, syariat Hindu bagi umat Hindu, dan syariat Nasrani bagi umat Nasrani, dan seterusnya. ${ }^{39}$

Hukum Islam sebagai sebuah ketentuan yang telah menyejarah dalam realitas kehidupan umat Islam merupakan realitas yang hidup. Meskipun demikian, secara teoretis hukum Islam hendaknya dilihat secara komprehensif. Karena pada kenyataannya, terdapat dua term yakni syariah dan fikih yang selalu dimaknai secara berbeda atau bahkan sering disamakan.

Hukum Islam merupakan bagian dari hukum nasional Indonesia, sebagai pelaksanaan sila pertama Pancasila dan Pasal 29 ayat (1) dan ayat (2) UUD 1945.

\footnotetext{
${ }^{38}$ Syamsul Anwar, Studi Hukum Islam Kontemporer, (Yogyakarta: Cakrawala, 2006), h. 11-15.

${ }^{39}$ Hazairin, Demokrasi Pancasila, (Jakarta: Bina Aksara, 1985), h. 33-34.
} 
Melalui jalur ini, ketentuan hukum Islam memerlukan kekuasaan Negara untuk pelaksanaannya mendapat jaminan konstitusional. ${ }^{40}$ Dari segi historis, fakta menunjukkan bahwa perjuangan umat Islam Indonesia tidak pernah berhenti sejak Islam masuk ke Nusantara, selama masa kerajaan dan kesultanan di pelbagai daerah. Demikian juga selama masa penjajahan pihak asing, umat Islam telah memperlihatkan keuletan dalam memperjuangkan pelaksanaan syariat Islam walaupun pihak kolonial, terutama Belanda, selalu berusaha menjauhkan umat Islam dari agamanya.

Memasuki masa kemerdekaan terlihat betapa sengitnya perdebatan dan perselisihan para the founding fathers dalam menentukan dasar Negara Indonesia, antara umat Islam nasionalis dan umat Islam sekuler yang mendapat dukungan dari masyarakat non muslim. Sejak memasuki awal kemerdekaan inilah, telah tampak perpecahan umat Islam Indonesia secara ideologis-politis. Persoalan ideologi Negara yang berkaitan dengan dasar negara Islami atau nasionalis telah menjadi konsumsi para elit politik. Kemunculan faham kebangsaan dengan dalih pluralisme selalu menjadi ganjalan dalam setiap kali syariat Islam dibicarakan melalui rancangan perubahan konstitusi atau perundang-undangan lainnya.

Dalam pandangan Abdullahi Ahmed an-Na'im, hukum Islam hanya bisa dipromosikan dan diterapkan melalui adaptasi dengan kebutuhan masyarakat Islam modern. Akan tetapi, betapapun akomodasinya prinsipprinsip hukum Islam dalam formalisasi hukum Negara tetap saja dilakukan melalui proses yang sekuler, dan ia bukan merupakan legislasi langsung prinsip-prinsip hukum Islam itu sendiri. ${ }^{41}$

Hukum Islam pada dasarnya merupakan hukum yang diderivasikan dari doktrin agama Islam. Karakter normatif sudah melekat pada doktrin agama Islam sehingga Islam memang dikenal sebagai agama hukum. Sedangkan dalam doktrin agama Islam, hukum dan akidah tidak bisa dipisahkan satu sama lainnya. Dari akidahlah institusi hukum itu dibangun, dan dengan menaati hukum, aspek akidah dapat dipertahankan. Dalam Islam, Alquran dan Sunah menjadi dua sumber utama dari semua aturan hukum yang harus ditaati oleh setiap muslim. ${ }^{42}$

Allah Swt. telah menetapkan hukum-hukum 'uqûbât

${ }^{40}$ Rifyal Ka'bah, Hukum Islam di Indonesia: Perspektif Muhammadiyah dan Nahdlatul Ulama (Jakarta: Universitas Yarsi Jakarta, 1999), h. 264.

41 Abdullahi Ahmed an-Na'im, Islam dan Negara Sekular: Menegosiasi Masa Depan Syariah, terj. Sri Murniati, (Bandung: Mizan, 2007), h. 36-37.

${ }^{42}$ Ratno Lukito, Hukum Sakral dan Hukum Sekuler: Studi tentang Konfik dan Resolusi dalam Sistem Hukum Indonesia, terj. Inyiak Ridwan Muzir (Jakarta: Pustaka Alvabet, 2008), h. 73-75. (pidana, sanksi, dan pelanggaran) dalam peraturan Islam sebagai "pencegah" dan "penebus". Sebagai pencegah, karena ia berfungsi mencegah manusia dari tindakan kriminal, dan sebagai penebus, karena ia berfungsi menebus dosa seorang muslim dari azab Allah di hari kiamat. Keberadaan 'uqûubât dalam Islam, yang berfungsi sebagai pencegah, telah disebutkan dalam Alquran, "Dan dalam qishâsh itu ada (jaminan kelangsungan) hidup bagimu, hai orang-orang yang berakal, supaya kamu bertakwa." (Q.s. al-Baqarah [2]: 179). Yang dimaksud dengan "ada jaminan kehidupan" sebagai akibat pelaksanaan qishâsh adalah melestarikan kehidupan masyarakat, bukan kehidupan sang terpidana. Sebab, bagi dia adalah kematian. Sedangkan bagi masyarakat yang menyaksikan penerapan hukuman tersebut-bagi orang-orang yang berakal—tentulah menjadi tidak berani membunuh, sebab konsekuensi membunuh adalah dibunuh. Demikian pula halnya dengan hukuman-hukuman lainnya, sebagai bentuk pencegahan terjadinya kriminalitas yang merajalela.

Sedangkan yang dimaksud dengan tindakan kriminal adalah suatu perbuatan yang dipandang tercela oleh syarak. Oleh karena itu, suatu perbuatan tidak dapat dikategorikan tindakan kriminal, kecuali apabila telah ditetapkan melalui nas syarak (Alquran, Hadis, dan apa-apa yang ditunjuk keduanya). Jika manusia melanggar perintah/larangan Allah, berarti dia telah melakukan perbuatan tercela, dan dianggap telah melakukan tindakan kriminal, sehingga harus dijatuhi hukuman atas kriminalitas yang dilakukannya. Sebab, tanpa pemberlakuan hukuman bagi para pelanggar, hukum tidak akan memiliki arti apa-apa. Suatu perintah tidak akan bernilai apa-apa jika tak ada balasan (hukuman) bagi pelanggar yang mengabaikan perintah tersebut. Syariat Islam telah menjelaskan bahwa pelaku kriminalitas akan mendapatkan hukuman, baik hukuman di dunia maupun hukuman di akhirat. Allah akan mengazab mereka di akhirat, dengan hukuman yang nyata. ${ }^{43}$

Demikianlah, ada banyak sekali ayat-ayat yang menggambarkan dasyatnya siksaan Allah di akhirat bagi orang-orang yang berdosa. Bagi yang memperhatikan dengan sungguh-sungguh, tentulah akan merasa ngeri sehingga tidak akan menganggap enteng semua hukuman di dunia. Akan tetapi, sungguh Maha Pemurah Allah Swt. bagi hamba-Nya yang beriman terhadap seluruh firman-firman-Nya, Dia sediakan alternatif yang mampu "menebus" dosa-dosanya di akhirat, yakni berupa serangkaian hukum pidana di dunia. Allah telah menjelaskan dalam Alquran dan Hadis, baik secara global maupun terperinci, hukum-hukum pidana bagi

${ }^{43}$ Perhatikan Q.s. Fâthir [35]:36; Q.s. al-Hîaqqah [69]: 35-37; dan Q.s. al-Ma'ârij [70]: 15-16. 
setiap pelaku kriminalitas, seperti: mencuri, berzina, mabuk, merontokkan gigi orang lain, dan sebagainya. Allah memberikan wewenang pelaksanaan hukuman tersebut kepada Imam (khalifah, pemimpin tunggal atas seluruh kaum muslimin) dan wakil-wakilnya (para hakim), yaitu dengan menerapkan sanksi-sanksi yang telah ditetapkan oleh Negara Islam (Khilafah), baik berupa hudûd, takzir, maupun kafârah (denda). Hukuman yang dijatuhkan ini akan menggugurkan siksaan di akhirat terhadap pelaku kejahatan.

Hukum pidana termasuk pada ranah hukum publik. Hukum pidana adalah hukum yang mengatur hubungan antarsubyek hukum dalam hal perbuatanperbuatan yang diharuskan dan dilarang oleh peraturan perundang-undangan dan berakibat diterapkannya sanksi berupa pemidanaan dan/atau denda bagi para pelanggarnya.

Dalam hukum pidana dikenal dua jenis perbuatan, yaitu kejahatan dan pelanggaran. Kejahatan ialah perbuatan yang tidak hanya bertentangan dengan peraturan perundang-undangan tetapi juga bertentangan dengan nilai moral, nilai agama, dan rasa keadilan masyarakat. Pelaku pelanggaran berupa kejahatan mendapatkan sanksi berupa pemidanaan, contohnya mencuri, membunuh, berzina, memperkosa, dan sebagainya. Sedangkan pelanggaran ialah perbuatan yang hanya dilarang oleh peraturan perundangan namun tidak memberikan efek yang tidak berpengaruh secara langsung kepada orang lain, seperti tidak menggunakan helm, tidak menggunakan sabuk pengaman dalam berkendaraan, dan sebagainya. Di Indonesia, hukum pidana diatur secara umum dalam Kitab Undangundang Hukum Pidana (KUHP), yang merupakan peninggalan dari zaman penjajahan Belanda, yang sebelumnya bernama Wetboek van Straafrecht (WvS). KUHP merupakan lex generalis bagi pengaturan hukum pidana di Indonesia di mana asas-asas umum termuat dan menjadi dasar bagi semua ketentuan pidana yang diatur di luar KUHP (lex specialis). ${ }^{44}$

Hukum pidana dalam Islam dinamakan "kisas", yaitu nyawa dibalas dengan nyawa, tangan dengan tangan. Namun demikian, dalam Islam ketika ada orang yang membunuh tidak langsung dibunuh, karena harus melalui proses pemeriksaan apakah yang membunuh itu sengaja atau tidak disengaja. Jika sengaja jelas hukumannya adalah dibunuh; Jika tidak disengaja wajib memerdekakan budak; Jika tidak ada, membayar dengan 100 onta; Jika mendapat pengampunan dari keluarga korban maka tidak akan terkena hukuman. ${ }^{45}$

44 Didapatkan dari http://id.wikipedia.org/wiki/Hukum, akses tanggal 20 November 2011.

${ }_{45}$ Di dapatkan dari http://id.wikipedia.org/wiki/Hukum, akses tanggal 20 November 2011.
Untuk tegaknya hukum materiil diperlukan hukum acara atau sering juga disebut hukum formil. Hukum acara merupakan ketentuan yang mengatur bagaimana cara dan siapa yang berwenang menegakkan hukum materiil dalam hal terjadi pelanggaran terhadap hukum materiil. Tanpa hukum acara yang jelas dan memadai, maka pihak yang berwenang menegakkan hukum materiil akan mengalami kesulitan menegakkan hukum materiil. Untuk menegakkan ketentuan hukum materiil pidana diperlukan hukum acara pidana; Untuk hukum materiil perdata, maka ada hukum acara perdata. Sedangkan; Untuk hukum materiil tata usaha negara, diperlukan hukum acara tata usaha negara; Hukum acara pidana harus dikuasai, terutama oleh para polisi, jaksa, advokat, hakim, dan petugas lembaga pemasyarakatan.

Hukum acara pidana yang harus dikuasai oleh polisi, terutama hukum acara pidana yang mengatur soal penyelidikan dan penyidikan, oleh karena tugas pokok polisi menurut hukum acara pidana (KUHAP) adalah melaksanakan tugas penyelidikan dan penyidikan. Yang menjadi tugas jaksa adalah penuntutan dan pelaksanaan putusan hakim. Oleh karena itu, jaksa wajib menguasai terutama hukum acara yang terkait dengan tugasnya tersebut. Sedangkan yang harus menguasai hukum acara perdata, termasuk hukum acara tata usaha negara, adalah advokat dan hakim. Hal ini disebabkan karena dalam hukum acara perdata dan juga hukum acara tata usaha negara, baik polisi maupun jaksa (penuntut umum) tidak diberi peran seperti halnya dalam hukum acara pidana. Advokatlah yang mewakili seseorang untuk memajukan gugatan, baik gugatan perdata maupun gugatan tata usaha negara, terhadap suatu pihak yang dipandang merugikan kliennya. Gugatan itu akan diperiksa dan diputus oleh hakim. Pihak yang digugat dapat pula menunjuk seorang advokat yang mewakilinya untuk menangkis gugatan tersebut.

Tegaknya supremasi hukum itu sangat tergantung pada kejujuran para penegak hukum itu sendiri yang dalam menegakkan hukum diharapkan benar-benar dapat menjunjung tinggi kebenaran, keadilan, dan kejujuran. Para penegak hukum itu adalah hakim, jaksa, polisi, advokat, dan petugas lembaga pemasyarakatan. Jika kelima pilar penegak hukum ini benar-benar menegakkan hukum dengan menjunjung tinggi nilainilai yang telah disebutkan di atas, maka masyarakat akan menaruh respek yang tinggi kepada penegak hukum. Dengan semakin tingginya respek itu, maka masyarakat akan terpacu untuk menaati hukum.

Dalam diskursus wacana formalisasi dan implementasi hukum pidana Islam, pandangan modernisme Islam dan fundamentalisme Islam cukup relevan untuk diangkat. Islam modernis memandang bahwa doktrin yang berhubungan dengan masalah-masalah muamalah 
hanya bersifat umum sehingga ijtihad harus digalakkan. Pandangan dasar ini erat hubungannya dengan persoalan hukum yang akan diberlakukan dalam negara. Oleh karena Islam modernis memandang bahwa tradisi awal Islam yang diberlakukan di zaman itu dapat diubah dengan ijtihad untuk menyesuaikannya dengan zaman yang baru. Hukum yang berlaku si suatu negara, bagi modernisme Islam, merupakan hukum hasil ijtihad terhadap dasar-dasar syariah sebagai sumber hukum. Pemberlakuannya dilakukan sebagai konsensus, yaitu keputusan seluruh wakil-wakil rakyat di parlemen. Sedangkan menurut modernisme Islam, hukum syariat adalah sumber hukum tertinggi di dalam negara. ${ }^{46}$ Bagi modernisme Islam, pelaksanaan ajaran dan hukum Islam itu harus mempertimbangkan keadaan tempat dan zamannya. Hukum Islam yang akan dilaksanakan ialah hukum Islam yang modern, yakni hukum yang sesuai dengan konteks Negara Islam yang bersangkutan.

Istilah syariat sebagai sumber hukum berbeda dengan pengertian syariah sebagai hukum. Sebagai sumber hukum, syariah tidak dilaksanakan secara langsung, melainkan terlebih dahulu perlu diperinci ke dalam suatu bentuk undang-undang yang memungkinkannya diberlakukan dalam sistem peradilan tertentu. Bagi modernisme Islam, peraturan hukum budîd dan qishâsh dipandang sebagai hukum maksimum (ultimum remedium). Rincian atas ketentuan tersebut tentu sangat diperlukan, misalnya kualifikasi delik $\underline{\text { hudûd. }}{ }^{47}$

Terkait dengan penegakan syariat Islam, dalam hal ini hukum pidana Islam di Indonesia, paling tidak terdapat empat kelompok cara pandang. Pertama, mereka yang menginginkan hukum pidana Islam ditegakkan seutuhnya dan tidak dicampuri dengan hukum-hukum lainnya yang sudah sah. Kedua, mereka yang meyakini kelaikan hukum pidana Islam yang nota bene setara dengan hukum Barat dan hukum Adat menjadi sumber hukum pidana di Indonesia. Ketiga, mereka yang meyakini bahwa syariat Islam itu harus ditegakkan seutuhnya sehingga harus ada pemerintah Islam. Keempat, mereka yang berpendapat bahwa yang paling penting ialah nilai-nilai syariat Islam dapat ditegakkan. ${ }^{48}$

Dari beberapa keterangan di atas, terdapat beberapa alternatif pelaksanaan hukum pidana Islam di Indonesia, yaitu: perubahan institusi, perubahan sistem

${ }^{46}$ Yusril Ihza Mahendra, Modernisme dan Fundamentalisme dalam Politik Islam: Perbandingan Partai Masyumi (Indonesia) dan Partai Jamấat-i-Islâmî (Pakistan), terj. Mun'im A. Sirry (Jakarta: Paramadina, 1999), h. 237-238.

47 Yusril Ihza Mahendra, Modernisme dan Fundamentalisme, h. 237-238.

${ }^{48}$ Topo Santoso, Membumikan Hukum Pidana Islam: Penegakan Syaiat dalam Wacana dan Agenda (Jakarta: Gema Insani Press, 2003), h. 146. hukum pidana Nasional menjadi sistem hukum pidana Islam, islamisasi hukum pidana Nasional, perluasan kompetensi Peradilan Agama, transformasi norma dan konsep hukum pidana Islam ke dalam hukum pidana Nasional, dan optimalisasi UU Pemerintahan Daerah.49 Dari masang-masing tawaran untuk memilih satu di antara beberapa tawaran tentu memiliki implikasi yang berbeda-beda, di samping dipengaruhi oleh faktorfaktor yang melingkupi persoalan masing-masingnya.

Pendeknya, penegakan hukum pidana Islam sejatinya sangat mendukung reformasi dalam bidang hukum pidana Nasional, dan juga sebaliknya. Syariat Islam sebagai hukum yang berasal dari wahyu Ilahi, sudah barang tentu akan memberikan jiwa dan ruh kepada hukum pidana Nasional yang dihormati dan dipatuhi oleh bangsa Indonesia yang nota bene mayoritas beragama Islam, juga bangsa Indonesia yang beragama selain Islam. Dalam konteks ini, sudah barang tentu formalisasi hukum pidana Islam di Indonesia ke dalam hukum pidana Nasional menjadi suatu kebutuhan dan tentu tidak akan melangggar dan menabrak aturan-aturan yang sudah ada. Meskipun praktiknya sudah ada, namun pergerakan dan perjalanan legislasi hukum pidana Islam dalam hukum pidana Nasional masih berjalan terseok-seok atau kalaupun berjalan masih terdapat kekurangan di pelbagai sisi. Bahkan yang lebih ironis, ada sebagian orang yang masih menganggap hukum pidana Islam sebagai hukum yang bertentangan dengan HAM. Maka, tawaran yang ada dalam tulisan ini menjadi alternatif sekaligus pilihan dalam kontekstualisasi hukum pidana Islam dalam bingkai tatanan hukum pidana Nasional, sebagai wujud merajut NKRI yang lebih indah dan lebih baik lagi.

Transformasi hukum pidana Islam dalam sistem hukum Nasional tetap menjadi agenda dan isu utama, jika hukum Islam tetap mengambil bagian dalam pola regulasi masyarakat Indonesia modern. Dalam konteks ini, Abdurrahman Wahid mengatakan bahwa dengan terintegrasinya hukum Islam dalam hukum Nasional, maka pelbagai persoalan epistemologis hukum Islam dapat terpecahkan dengan sendirinya. Untuk memperoleh transformasi tersebut, hukum Islam harus mampu mengembangkan watak dinamis bagi dirinya, di antaranya dengan mampu menjadikan dirinya penunjang transformasi hukum Nasional di alam pembangunan ini. Hukum Islam harus memiliki pendekatan multidimensional kepada kehidupan, dan tidak hanya terikat kepada ketentuan normatif yang telah mengendap sekian lama, bahkan hampir-hampir menjadi fosil..$^{50}$

\footnotetext{
${ }^{49}$ Topo Santoso, Membumikan Hukum Pidana Islam, h. 99-100.

${ }^{50}$ Abdurrahman Wahid, Islam Kosmopolitan: Nilai-nilai Indonesia dan Transformasi Kebudayaan (Jakarta: The Wahid Institute, 2007), h. 50.
} 
Transformasi hukum pidana Islam dalam sistem hukum Indonesia kontemporer pada pokoknya dapat disandarkan pada dua argumentasi utama. Pertama, argumentasi kultural, historis, dan sosiologis. Kedua, argumentasi normatif dan legal konstitusional. Jika argumentasi kultural historis dan sosiologis terkait dengan fakta empiris penerimaan masyarakat terhadap eksistensi hukum syariah Islam dalam sistem hukum Indonesia kontemporer sebagai rangkaian yang tak terpisahkan dengan eksistensinya pada masa pra kemerdekaan, maka argumentasi normatif dan legal konstitusional tentu saja terkait dengan sandaran politik hukum secara konstitusional berdasarkan UUD 1945 dan tuntutan hakiki hukum Islam.

Fakta empiris hukum Islam sebagai the living law dalam interaksi keseharian masyarakat Indonesia, tentu cukupjelas menunjukkanbahwaeksistensihukumsyariat Islam dalam sistem hukum Indonesia telah sungguhsungguh memiliki "akar historis" dalam kesadaran masyarakat Islam, seiring dengan pertumbuhan dan perkembangan ajaran agama Islam itu sendiri. Akar historis eksistensi hukum Islam dimaksud, antara lain direpresentasikan lewat teori Receptio in Complexu dan teori Receptie. ${ }^{51}$

Pembinaan hukum Nasional ini, termasuk dalam hukum pidana, telah dilaksanakan dalam waktu yang lama. GBHN sejak 1973 hingga 1999 telah menggariskan upaya pembangunan dan pembentukan hukum Nasional, meskipun pada praktiknya penuh dengan pengaruh politik penguasa. GBHN 1999 yang merupakan produk reformasi, juga menegaskan arah kebijakan hukum nasional ini:

"Menata sistem hukum Nasional yang menyeluruh dan
terpadu dengan mengakui dan menghormati agama dan
hukum adat serta memperbarui perundang-undangan
warisan kolonial dan hukum Nasional yang diskriminatif,
termasuk ketidakadilan gender dan ketidaksesuaiannya
dengan tuntutan reformasi melalui program legislasi."

Dari ungkapan tersebut dapat dipahami bahwa pembangunan hukum Nasional secara garis besar bersumber pada: hukum Adat, hukum Agama, dan hukum Mancanegara, khususnya dari hukum Barat. ${ }^{52}$ Sebab secara teoretis sumber-sumber hukum Islam, hukum Adat, hukum Barat, dan lain-lain mempunyai nilai dan peluang yang sama untuk dijadikan sebagai

${ }^{51}$ Penjelasan tentang teori Receptio in Complexu dan teori Receptie ini dapat dilihat dalam tulisan Muhammad Daud Ali, Hukum Islam: Pengantar Ilmu Hukum dan Tata Hukum Islam di Indonesia (Jakarta: PT. Raja Grafindo Persada, 1999), h. 219. Juga Muhammad Idris Ramulyo, Asas-asas Hukum Islam: Sejarah Timbul dan Berkembangnya Hukum Islam di Indonesia (Jakarta: Sinar Grafika, 1995), h. 58-59.

52 A. Qodri Azizy, Eklektisisme Hukum Nasional: Kompetisi antara Hukum Islam dan Hukum Umum (Yogyakarta: Gama Media, 2002), h. 111 . sumber dalam implementasi pemidanaan di Indonesia. Bukan hanya sekadar eksistensi umat Islam di Indonesia yang mayoritas dan terbesar jumlahnya di dunia, tetapi juga efektivitas sanksi pidananya.

Pemidanaan dalam Islam harus didudukkan secara rasional pada dunia modern. Hal-hal yang bersifat teknis pelaksanaan sanksi pidana dapat saja menyesuaikan dengan kemajuan zaman. Tetapi tidak meninggalkan prinsip dasar pemidanaan yang bertujuan meminimalisasikan terjadinya kejahatan kemanusiaan. Memilih jenis-jenis pemidanaan yang berakar pada kitab suci Alquran dan Hadis yang memiliki nilai spiritual dan berdimensi keakhiratan dapat berpengaruh secara psikologis dalam penerapannya. Sebaliknya, menerapkan konsep sanksi pidana yang berdasar pada alam pikiran manusia semata dan hasilnya tidak efektif cenderung dapat berubah dan ditinggalkan oleh perkembangan zaman. Dalam konteks ini, maka Islam memberikan alternatif pemidanaan berupa kisas, diat, dan takzir. Pemidanaan tidak harus dilihat pada ukuran primitif dan modern tetapi lebih mengutamakan efektivitas.

\section{Penutup}

Dari uraian yang telah dijelaskan di atas, dapat dinyatakan bahwa penegakan dan formalisasi hukum pidana Islam ke dalam hukum pidana Nasional akan saling melengkapi sekaligus menjadi jawaban atas problem kriminalitas yang hingga kini tidak pernah usai. Sudah saatnya pemerintah merekonstruksi hukum pidana yang ada, dan sudah saatnya pula memantikkan nilai-nilai hukum pidana Islam dalam hukum Nasional. Patut pula diperhatikan obyektivikasi hukum Islam yang menjadikan hukum Alquran terlebih dahulu sebagai hukum positif yang pembentukannya atas persetujuan bersama warga negara. Di sini perlu juga ditegaskan bahwa hukum agama merupakan unsur mutlak hukum Nasional. Tertib hukum masyarakat Indonesia, dalam hal ini, membutuhkan adanya peraturan perundangundangan yang sesuai dengan/dan bersumber dari ajaran-ajaran agama.[]

\section{Pustaka Acuan}

Abdillah, Masykuri, "Posisi Hukum Pidana Islam dalam Konteks Politik Hukum dan Perundangan Indonesia", makalah seminar Nasional Hukum Pidana Islam: Deskripsi, Analisis Perbandingan dan Kritik Konstruktif, Fakultas Syariah IAIN Syarif Hidayatullah Jakarta, 22-23 Juni 1999.

Agafi, Ropaun Rambe dan Mukri, Implementasi Hukum Islam, Jakarta: PT Perca, 2001.

Ali, Muhammad Daud, "Kedudukan Hukum Islam 
dalam Sistem Hukum Nasional", dalam Taufik Abdullah dan Sharon Shiddiqie (ed.), Tradisi dan Kebangkitan Islamdi Asia Tenggara, Jakarta: LP3ES, 1989.

Ali, Muhammad Daud, Hukum Islam: Pengantar Ilmu Hukum dan Tata Hukum Islam di Indonesia, Jakarta: PT. Raja Grafindo Persada, 1999.

Arifin, Busthanul, "Pikiran-pikiran tentang Hukum Pidana Kita", Makalah Seminar Nasional "Hukum Pidana Islam: Deskripsi, Analisis Perbandingan dan Kritik Konstruktif, Jakarta, IAIN Syarif Hidayatullah Jakarta, 22-23 Juni 1999.

-.---.----, Pelembagaan Hukum Islam di Indonesia: Akar Sejarah, Hambatan dan Prospeknya, Jakarta: Gema Insani Press, 1996.

Asshiddiqie, Jimly, Pembaharuan Hukum Islam, Bandung: Aksara, 1996.

Audah, Abd al-Qadir, Criminal Law of Islam, Karachi: International Publisher, 1987.

Azhari, Muhammad Tahir, Negara Hukum: Suatu Studi tentang Prinsip-prinsipnya Dilihat dari Segi Hukum Islam, Implementasinya pada Periode Negara Madinah dan Masa Kini, Jakarta: Bulan Bintang, 1992.

Azizy, A. Qodri, Eklektisisme Hukum Nasional: Kompetisi antara Hukum Islam dan Hukum Umum, Yogyakarta: Gama Media, 2002.

Azra, Azyumardi, Jaringan Global Lokal Islam Nusantara, Bandung: Mizan, 2002.

Hadjar, Ibnu, "Syariat Islam dan Hukum Positif di Indonesia", diakses 28 November 2011, dalam http://journal.uii.ac.id.

Hazairin, Demokrasi Pancasila, Jakarta: Bina Aksara, 1985.

Jâbir, al-, Muhammad al-Dâsûqî dan Amînah, Muqaddimah fî̀ Dirâsah al-Fiqh al-Islâmî, Qatar: Dawhah, 1990.

Jawziyah, al-, Ibn al-Qayyim, I'làm al-Muwaqqi în, dalam Abdul Rauf Sadan (ed.), Ttp. Maktabah alKulliyah al-Azhariyyah, t.th.

Ka’bah, Rifyal, "Reformasi Metodologi Pengembangan Hukum Islam", dalam Mimbar Hukum: Aktualisasi Hukum Islam, no. 34, Tahun X 1999.

--------, Hukum Islam di Indonesia: Perspektif Muhammadiyah dan Nahdlatul Ulama, Jakarta: Universitas Yarsi Jakarta, 1999.
Kâmil, Mûsâ, al-Madkhal Ilâ Tasyrî' al-Islâmî, Bayrût: Mu'assasah al-Risâlah, t.th.

Lev, Daniel S., Hukum dan Politik di Indonesia, (terj.), Jakarta: LP3ES, 1990.

Lukito, Ratno, Hukum Sakral dan Hukum Sekuler: Studi tentang Konflik dan Resolusi dalam Sistem Hukum Indonesia, terj. Inyiak Ridwan Muzir, Jakarta: Pustaka Alvabet, 2008.

Mahendra, YusrilIhza, Modernisme dan Fundamentalisme dalam Politik Islam: Perbandingan Partai Masyumi (Indonesia) dan Partai Jamâ'ah Islâmî (Pakistan), terj. Mun'im A. Sirry, Jakarta: Paramadina, 1999.

Mustofa, Hukum Islam Kontemporer, Jakarta: Sinar Grafika, 2003.

$\mathrm{Na}$ 'im, al-, Abdullahi Ahmed, Islam dan Negara Sekular: Menegosiasi Masa Depan Syariah, ter. Sri Murniati, Bandung: Mizan, 2007.

Ramulyo, Muhammad Idris, Asas-asas Hukum Islam: Sejarah Timbul dan Berkembangnya Hukum Islam di Indonesia, Jakarta: Sinar Grafika, 1995.

Santoso, Topo, Membumikan Hukum Pidana Islam: Penegakan Syaiat dalam Wacana dan Agenda, Jakarta: Gema Insani Press, 2003.

Schatch, Joseph, An Introduction to Islamic Law, London: Calender, 1996.

Shîrâzî, al-, Abû Ishâq, al-Lumầ fî̀ Ushîul al-Fiqh, Libanon: Dâr al-Kutub, $475 \mathrm{H}$.

Siregar, Bismar, Hukum Acara Pidana, Jakarta: Bina Cipta, 1987.

Sirin, Khoiron, "Legislasi Hukum Islam di Indonesia: Sebuah Harapan-harapan Sosiologis", Jurnal alMuqarin, no. 2/Th.IV/1998.

Suny, Ismail, "Kedudukan Hukum Islam dalam Sistem Ketatanegaraan Indonesia", dalam Amrullah Ahmad, dkk. (ed.), Dimensi Hukum Islam dalam Sistem Hukum Nasional, Jakarta: Gema Insani Press, 1996.

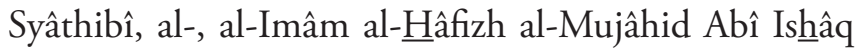
Ibrâhim bin Mûsâ al-Gharnathî, al-Muwâfaqat fî̀ Ushûl al-Ahkâm, Bayrût: Dâr al-Fikr, t.th.

Wahid, Abdurrahman, Islam Kosmopolitan: Nilai-nilai Indonesia dan Transformasi Kebudayaan, Jakarta: The Wahid Institute, 2007. 